\title{
Functionality and chemical composition of maize-okara flour blends on biscuit quality
}

\section{Folasade Maria Makinde, Osaruguwe Dan-Aighewi Tifu}

\author{
Bowen University, Iwo, Osun State, Nigeria
}

Keywords:

Maize

Okara

Functionality

Nutrients

Biscuits

\section{Article history:}

Received 21.03.2021

Received in revised

form 23.06.2021

Accepted 16.07.2021

\section{Corresponding \\ author:}

Folasade Maria

Makinde

E-mail:

sademakin@yahoo.com

DOI: $10.24263 / 2310$ -

1008-2021-9-1-9

\section{Abstract}

Introduction. Cereal grains are generally used as relatively inexpensive raw material in snack foods in developing countries. In order to enhance the nutritional quality of maize based flour, an attempt has been made to incorporate okara (a by-product) from soy milk production.

Materials and methods. Flour blends were developed by supplementing maize flour with okara flour $(\mathrm{w} / \mathrm{w})$ at $0,10,20$, 30,40 and $50 \%$ levels. The $100 \%$ maize flour served as the control. Biscuits were prepared from the flour blends. The functional and pasting properties of the blends as well as physical, chemical and sensory properties of the biscuit samples were determined.

Results and discussion. The flour blends developed in this study have distinct functional characteristics, providing added value to a waste product. Flour samples also varied significantly $(\mathrm{p} \leq 0.05)$ in the pasting properties. The results on biscuit samples revealed the following ranges: physical properties; weight 15.69 to $18.18 \mathrm{~g}$, diameter 11.39 to $13.62 \mathrm{~mm}$, thickness 1.59 to $1.71 \mathrm{~mm}$ and spread ratio 6.99 to $8.06 \mathrm{~mm}$; Proximate parameters- moisture content 4.53 to $5.68 \%$, ash 1.00 to $1.63 \%$, protein 7.8 to $18.6 \%$, fat 17.8 to $21.2 \%$, fibre 1.91 to $5.28 \%$, carbohydrate 47.6 to $67.0 \%$ and energy 392.50 to $409.58 \mathrm{kCal} / 100 \mathrm{~g}$; anti-nutrients; phytate 0.03 to $0.06 \mathrm{mg} / \mathrm{g}$, oxalate 0.36 to $0.73 \mathrm{mg} / \mathrm{g}$ and tannin 0.53 to $1.47 \mathrm{mg} / \mathrm{g}$. The incorporation of okara increased the protein, fat and ash contents of biscuit samples while the carbohydrate content decreased. The biscuit samples presented different concentration of tannin; however samples prepared from $100 \%$ maize flour were devoid of phytate and oxalate. Sensory characteristics of biscuit prepared from 100\% maize flour (control) varied significantly ( $\leq \leq 0.05$ ) with those containing 10 to $50 \%$ okara inclusion level. However, biscuits containing $40 \%$ inclusion level of okara were most preferred.

Conclusion. The research work provide added value to edible waste product of food industries offering a promising alternative to address food and environmental problems in African tropics. 


\section{Introduction}

Snacks are easy-to-prepare food eaten in place of a main meal or between main meals. Biscuit is a term used for a variety of baked, commonly flour based food product. They are nutritive snacks from unpalatable dough transformed into appetizing products through the application of oven heat [1]. Biscuits are widely accepted and consumed in many countries. The consumption of biscuits, wafers and short bread, has become very popular in Nigeria, especially among children and young adults [2]. Wheat flour is a critical and principal raw material in biscuit production. Its superiority over other cereals is due to the presence of gluten which confers unique texture and taste to wheat based products. Non-wheat flours are also used in baked goods with distinct attributes though they do not contain gluten. Some are particularly higher in protein, dietary fibre, phytochemicals and array of essential vitamins and minerals than wheat flour [3]. Non- wheat flours are obtained from other cereals, legumes, tubers, and root crops. Though, the utilization of these ingredients has gained ground in the production of snacks locally, but the use of composite flour of two important agricultural produce such as maize and okara (by-product from soy milk production) remain lesser known.

Maize (Zea mays) is an annual cereal crop belonging to the Poaceae family. Maize is one of the oldest cultivated grains and one of the most productive crop species with a global average yield of more than 4 tonnes per hectare [4]. Maize has been in the diet of Nigerians for many years and has been processed into a wide range of varieties by the different tribes in Nigeria usually done by cooking, roasting, frying, pounding or crushing to produce delicacies such as "tuwo", "ogi" and "dokunnu" as reported by Oladejo and Adetunji [5].The grains could also be processed into a wide variety of product such as starch, flour, grit, popcorn and breakfast cereals. Maize kernel is composed of $70-75 \%$ starch, $8-10 \%$ protein, $4-5 \%$ lipid, $1-3 \%$ sugar and $1-4 \%$ ash [6]. Maize germ contains about $45-50 \%$ oil which is made up of $14 \%$ saturated fatty acids, $30 \%$ monosaturated fatty acids, and $56 \%$ polyunsaturated fatty acids [7]. Most importantly, the yellow maize variety is a good source $\beta$-carotene (precursor of vitamin A) which is essential for good vision and at high concentrations also acts as a pro-antioxidant and induces apoptosis of colon cancer cells, leukaemia cells, melanoma cancer cells and gastric cancer cells, thus rendering potent chemopreventive effects [8].

Soybean (Glycine max) probably originated in Eastern China and is widely cultivated as a farm crop. It has been reported that soybean is a very rich source of protein, fat, phytochemicals and minerals such as copper, zinc and manganese [9]. Okara is a by-product from soy milk production; it is solid non-soluble fraction obtained from hydrothermal treatment of the crushed soybeans. This residue is generally discarded causing a significant environmental problem because it is susceptible to putrefaction due to its high moisture content $(80 \%)$ as reported by Ostermann-Porcel [10]. Though Asian countries have found many ways to use okara, most other countries regarded it as agro waste with very little value hence used as animal feed. Okara has yellowish white colour with a neutral, smooth flavor. Asides, it is worthy to note that this by-product contains many beneficial components; hence it has attracted research interest as functional food. Okara is packed with a significant number of proteins, isoflavones, soluble and insoluble fibres, soya saponins, and other mineral elements, which are all attributed with health merits [11].

Maize is a cereal with miniscule protein content, and like other cereal grains; it is deficient in lysine and tryptophan while okara is a soy derivative that provides all the essential amino acids needed to fulfil human nutritional requirement for growth and maintenance [10]. Moreso, there is a high need for the development of gluten-free food in order to attend to an increasing food demand; hence, a source of suitable nutrients for celiac sufferers could be found in soybean derivative (okara) and maize.

The present study investigates the effect of supplementation of maize with okara on biscuit quality. 


\section{Materials and methods}

\section{Materials}

Dried yellow maize (Zea mays) grains and soybean (Glycine max) were obtained from the International Institute of Tropical Agriculture (IITA), Ibadan. The varieties used were Sammanz 35 (maize) and TGx 1835-10e (soybean) developed by IITA in collaboration with National Cereal Research Institute (NCRI). Other raw materials such as margarine, food grade salt, granulated sugar, food flavouring and eggs were purchased from a local market in Iwo, Osun state, Nigeria. The chemicals used for the analyses were of analytical grade.

\section{Preparation of research samples}

Okara flour. Okara flour was prepared using the method reported by Ostermann-Porcel [10]. Soybean (TGx 1835-10e) seeds were soaked in water for $8 \mathrm{hr}$ at ambient temperature. The soaked seeds were ground in a blender with addition of water to enhance the grinding. The ground paste was then thermally treated at $90^{\circ} \mathrm{C}$ for $20 \mathrm{~min}$ in order to reduce the activity of the trypsin inhibitor and deactivate the lipoxygenase enzyme which causes the unpleasant taste. The soybean slurry is separated from the ground paste using muslin cloth and the residue constitutes the wet okara. The residue was dried using laboratory drier and milled into flour using Phillip laboratory blender (HR2811 model). The okara flour was sifted using a $60 \mathrm{~mm}$ mesh, packed in glass container and kept in freezer $\left(-4^{\circ} \mathrm{C}\right)$ pending analyses.

Maize flour. Fully dried yellow maize (Sammaz 39) seeds were weighed and manually sorted to remove bad grains and foreign materials. The sorted grains were weighed again and milled into flour using Phillip laboratory blender (HR2811 model). The maize flour was sifted using a $60 \mathrm{~mm}$ mesh, packed in glass container and kept in freezer ($4^{\circ} \mathrm{C}$ ) pending analyses.

\section{Experimental plan}

Maize flour was supplemented with okara flour at $0 \%$ (sample A), 10\% (sample B), $20 \%$ (sample C), 30\% (sample D), 40\% (sample E) and 50\% (sample F). Table 1 shows the various ingredients in the preparation of biscuit samples.

\section{Biscuits}

Biscuit samples were produced from the blends using reported method [12]. Maize flour was supplemented with okara flour at 0,10, 20,30, 40 and 50\%. After the baking process, the biscuit samples were allowed to cool to ambient temperature and packed in airtight glass containers for subsequent laboratory analyses. The biscuit samples prepared with $100 \%$ maize flour served as the control. Figure 1 shows biscuit samples prepared from the flour blends. 
Table 1

Laboratory formulations of ingredients used in the preparation of biscuits (g)

\begin{tabular}{|c|c|c|c|c|c|c|c|}
\hline Sample & $\begin{array}{c}\text { Maize } \\
\text { flour }\end{array}$ & $\begin{array}{c}\text { Okara } \\
\text { flour }\end{array}$ & Margarine & Sugar & $\begin{array}{c}\text { Baking } \\
\text { powder }\end{array}$ & Egg & Salt \\
\hline A & 300 & 0 & 50 & 30 & 0.05 & 90 & 0.5 \\
\hline B & 270 & 30 & 50 & 30 & 0.05 & 90 & 0.5 \\
\hline C & 240 & 60 & 50 & 30 & 0.05 & 90 & 0.5 \\
\hline D & 210 & 90 & 50 & 30 & 0.05 & 90 & 0.5 \\
\hline E & 180 & 120 & 50 & 30 & 0.05 & 90 & 0.5 \\
\hline F & 150 & 150 & 50 & 30 & 0.05 & 90 & 0.5 \\
\hline
\end{tabular}

A-100\% maize flour;

B- $90 \%$ maize flour $+10 \%$ okara flour;

C- $80 \%$ maize flour $+20 \%$ okara flour;
D-70\% maize flour $+30 \%$ okara flour; E- $60 \%$ maize flour $+40 \%$ okara flour;

F-50\% maize flour $+50 \%$ okara flour
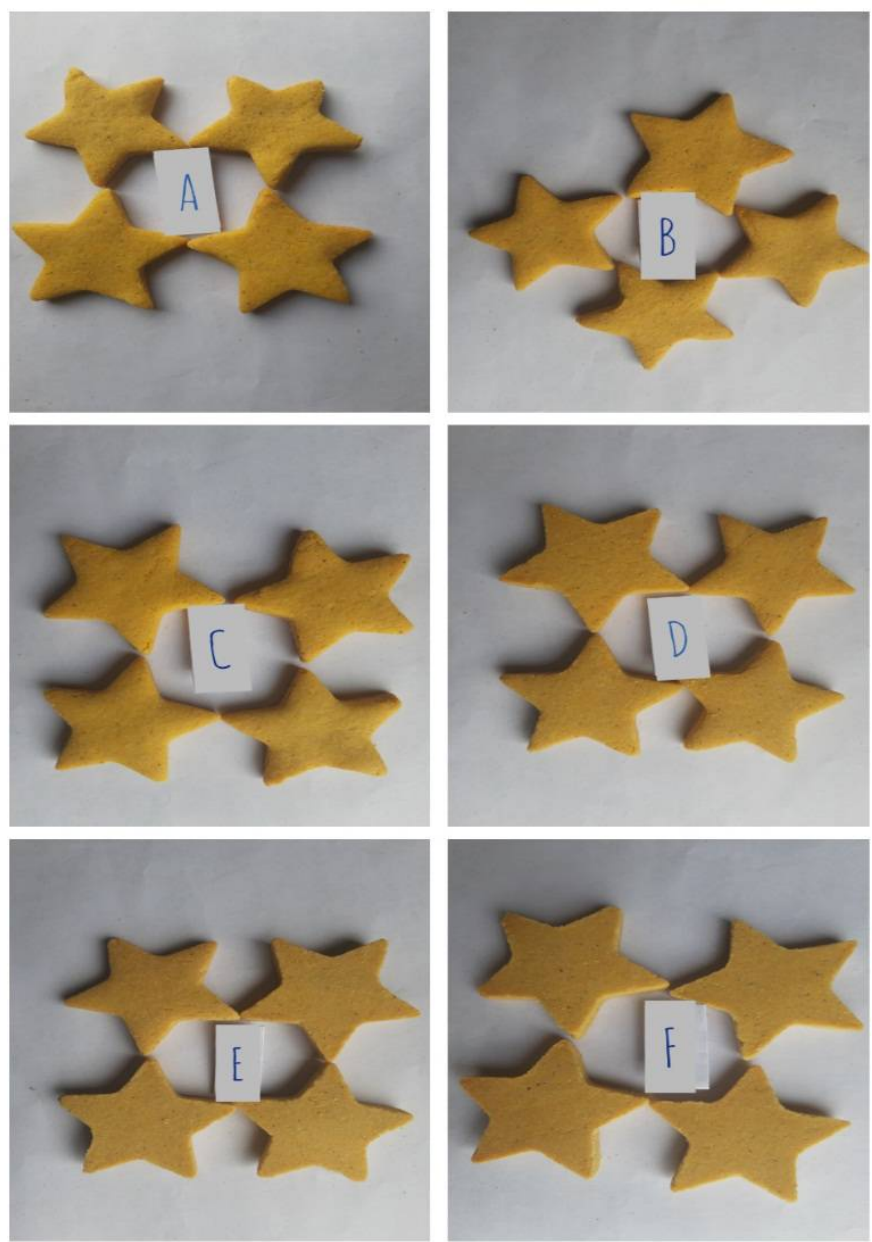

Figure 1. Biscuit samples with:

A-100\% maize flour;

B- $90 \%$ maize flour $+10 \%$ okara flour;

C- $80 \%$ maize flour $+20 \%$ okara flour;
$\mathrm{D}-70 \%$ maize flour $+30 \%$ okara flour;

E- $60 \%$ maize flour $+40 \%$ okara flour;

F-50\% maize flour $+50 \%$ okara flour 


\section{Description of methods}

Functional properties of flour blends. The bulk density (loosed and packed) of the flours was determined by the gravimetric method described by Appiah et al [13]. Water and oil absorption capacities were determined using the procedures described by Sofi et al [14]. Additionally, the swelling power and starch solubility of the flour samples were determined using the methods reported by Wani et al. [15].

Pasting properties of flour blends. The pasting behaviour of the flour samples was measured in a Rapid Visco Analyzer (Model: RVA-4, Newport Scientific Pty. Ltd., Sydney, Australia, 1995) and Thermocline for Windows software was used to evaluate the pasting properties.

Physical characteristics of biscuit samples. The biscuit samples were analysed for physical properties such as diameter, thickness, weight and spread ratio as described by AACC [16]. The surface colour of biscuits was determined according to values based on a CIE L*a*b* color scale using Konica Minolta Chroma Meter CR-400. All analyses were carried out in triplicate.

Chemical analyses of biscuit samples. Standard methods according to the AOAC [17] were used to determine the proximate composition. The caloric value was estimated $(\mathrm{kCal} / 100 \mathrm{~g})$ by multiplying the percentage crude protein, crude lipid and carbohydrate by the recommended factors of 2.44, 8.37 and 3.57 respectively and then taking the sum as described by Ekanayake et al [18]. The titration method described by Oladele et al. [19] was used to determine the oxalate and phytate contents of biscuit samples. Tannin content was determined by the method described by Mugaboa et al [20]. All analyses were carried out in triplicate.

Sensory characteristics of biscuit samples. The sensory evaluation of the biscuit samples was performed by 25 semi-trained panellists. The panellists were asked to evaluate each sample based on the colour, taste, aroma, sweetness, hardness, crunchiness and overall quality using a 5-point Hedonic scale (5- like extremely and 1- dislike extremely).

\section{Statistical analysis}

Statistical analyses were conducted using Statistical Package for the Social Sciences version 17.0software (SPSS Inc., Chicago, IL, USA). Significant differences between the mean values were determined using Duncan multiple range tests at a significance level of $\mathrm{p} \leq$ 0.05 .

\section{Results and discussion}

Functional properties of maize- okara flour blend

Functional properties of the flour blends were presented in Table 2. Supplementation of maize flour with okara flour had significant effect $(\mathrm{p} \leq 0.05)$ on the functional parameters under consideration. The loosed and packed bulk densities of the composite flours varied between $0.45-0.55 \mathrm{~g} / \mathrm{cm}^{3}$ and $0.62-0.72 \mathrm{~g} / \mathrm{cm}^{3}$, respectively. 
Functional properties of flour blends

\begin{tabular}{|c|c|c|c|c|c|c|}
\hline Sample & \multicolumn{2}{|c|}{$\begin{array}{c}\text { Bulk density }\left(\mathbf{g} / \mathbf{c m}^{3}\right) \\
\text { Loosed } \\
\text { Packed }\end{array}$} & $\begin{array}{c}\text { WAC } \\
(\mathbf{g} / \mathbf{m L})\end{array}$ & $\begin{array}{c}\text { OAC } \\
(\mathbf{g} / \mathbf{m L})\end{array}$ & $\begin{array}{c}\text { Swelling } \\
\text { Power } \\
(\%)\end{array}$ & $\begin{array}{c}\text { Starch } \\
\text { Solubility } \\
(\%)\end{array}$ \\
\hline $\mathbf{A}$ & $0.55^{\mathrm{b}} \pm 0.02$ & $0.70^{\mathrm{c}} \pm 0.01$ & $1.91^{\mathrm{a}} \pm 1.02$ & $1.45^{\mathrm{b}} \pm 0.07^{\mathrm{b}}$ & $6.89^{\mathrm{d}} \pm 0.09$ & $12.79^{\mathrm{e}} \pm 0.72$ \\
$\mathbf{B}$ & $0.47^{\mathrm{a}} \pm 0.02$ & $0.72^{\mathrm{c}} \pm 0.01$ & $1.90^{\mathrm{a}} \pm 0.13$ & $1.44^{\mathrm{b}} \pm 0.35^{\mathrm{b}}$ & $5.88^{\mathrm{c}} \pm 0.09$ & $8.19^{\mathrm{d}} \pm 0.20$ \\
$\mathbf{C}$ & $0.48^{\mathrm{a}} \pm 0.00$ & $0.67^{\mathrm{b}} \pm 0.00$ & $2.38^{\mathrm{b}} \pm 1.24$ & $1.35 \pm 0.60^{\mathrm{ab}}$ & $5.79^{\mathrm{bc}} \pm 0.04$ & $7.12^{\mathrm{cd}} \pm 0.11$ \\
$\mathbf{D}$ & $0.48^{\mathrm{a}} \pm 0.00$ & $0.63^{\mathrm{a}} \pm 0.00$ & $2.37^{\mathrm{b}} \pm 2.03$ & $1.36^{\mathrm{ab}} \pm 1.31$ & $5.57^{\mathrm{bc}} \pm 0.14$ & $5.92^{\mathrm{bc}} \pm 0.64$ \\
$\mathbf{E}$ & $0.45^{\mathrm{a}} \pm 0.00$ & $0.62^{\mathrm{a}} \pm 0.01$ & $2.43^{\mathrm{b}} \pm 0.37$ & $1.35^{\mathrm{ab}} \pm 0.04$ & $5.54^{\mathrm{b}} \pm 0.13$ & $5.12^{\mathrm{b}} \pm 0.81$ \\
$\mathbf{F}$ & $0.45^{\mathrm{a}} \pm 0.00$ & $0.62^{\mathrm{a}} \pm 0.00$ & $2.48^{\mathrm{b}} \pm 0.80$ & $1.09^{\mathrm{a}} \pm 0.41$ & $4.99^{\mathrm{a}} \pm 0.17$ & $3.03^{\mathrm{a}} \pm 0.49$ \\
\hline
\end{tabular}

Key a-e: Means with the same superscripts within each row are not significantly different $(\mathrm{p} \geq 0.05)$

Highest values were identified in the control sample (100\% maize flour). Lower bulk density of the composite flour blends gives an indication that they were lighter compared with the control. This might be due to the lower particle size of okara flour than that of maize flour. Such flour samples would be an advantage in preparation of complementary foods though their usage may produce less extensible and fluid dough due to high water uptake.

The water absorption capacity (WAC) of the flour samples varied between 1.91-2.48 $\mathrm{g} / \mathrm{mL}$ and it showed a significant difference $(\mathrm{p} \leq 0.05)$ with okara interaction. Composite flours had higher water absorption capacity than the control sample. This could indicate the fact that addition of okara flour improves the water absorption capacity of maize flour. This may be as a result of the increase in the protein content of blends containing okara compared with the control. Protein has both hydrophilic and hydrophobic properties, and so has affinity for water molecule in foods. Moreso, more hydrophilic constituents, such as dietary fibre contributes to high WAC in food ingredients.

Result shows that the maximum oil absorption capacity (OAC) was observed in the control sample, while the blend containing 50\% maize flour and 50\% okara flour had the lowest value. Significant decrease in OAC was observed as the percentage of okara flour in the blend increases. The decrease indicated the diluting effect of okara on oil absorption capacity of maize flour. It has been reported that variations in the content of non-polar side chains which might bind the hydrocarbon side chains of oil, explains differences in the oil binding capacity of flours [21].

Decrease in swelling power was noted in the flour blends as the level of okara increases. Swelling power of starch was reported to be inhibited by amylose and lipids [22]. In essence, the higher fat content observed in flour blends supplemented with okara was responsible for lower swelling power compared with the control. Reports on the relationship between swelling power, amylose content, lipids and amylopectin fine structure concluded that amylose and lipids inhibited swelling power while a high proportion of amylopectin long chains (DP $>35$ unit chains) resulted in increased swelling power [23].

A decline in starch solubility was noticed in the flour samples as the level of okara in the blend increases. Higher solubility observed in the control sample compared with composite blends could be associated with high content of amylose which leaches out easily during the swelling process as reported by Sanni et al [24]. 


\section{Pasting properties of maize-okara blends}

Significant differences $(\mathrm{p} \leq 0.05)$ were observed among pasting properties of the flour samples as presented in Table 3. A peak viscosity of 30.34 RVU which was significantly different from other flour blends was observed in the control sample, while the least peak viscosity of $5.34 \mathrm{RVU}$ was recorded in sample F. Blended flours recorded lower peak viscosity compared with the control. Peak viscosity is the maximum viscosity developed during or soon after the heating portion of the sample. It is often correlated with the final product quality and also provides an indication of the viscous loads likely to be encountered during mixing [25].

The trough viscosity ranged from $4.84 \mathrm{RVU}$ in sample $\mathrm{F}$ to $26.78 \mathrm{RVU}$ in sample A. The break down viscosities of the composite flour ranged from $0.05 \mathrm{RVU}$ (sample E) to 3.55 RVU (sample A). It is an indication of breakdown or of the starch gel during cooking which often is used as an index of paste stability. The final viscosity ranged from 7.50 RVU in sample F to 72.56 RVU (sample A). The final viscosity indicated the re-association of starch granules especially amylose during cooling time after gelatinization [26].

This study showed a setback viscosity range of 2.64 to 45.78 RVU. Sasaki et al. [27] indicated that lower amylase content is associated with higher peak viscosity. Generally, the pasting viscosities and swelling power of flour are positively correlated [28]. Thus, the higher the swelling power of flour, the higher the pasting viscosities. The result corroborates the trend earlier observed on swelling power of the composite flour (Table 2). Variation exists in the peak time recorded for the flour samples. The pasting temperature of the control sample was significantly different compared with the blends containing different level of okara flour.

Table 3

Pasting properties of flour blends

\begin{tabular}{|c|c|c|c|c|c|c|c|}
\hline Sample & $\begin{array}{c}\text { Peak } \\
\text { Viscosity } \\
\text { (RVU) }\end{array}$ & $\begin{array}{c}\text { Trough } \\
\text { Viscosity } \\
\text { (RVU) }\end{array}$ & $\begin{array}{c}\text { Breakdown } \\
\text { Viscosity } \\
\text { (RVU) }\end{array}$ & $\begin{array}{c}\text { Final } \\
\text { Viscosity } \\
\text { (RVU) }\end{array}$ & $\begin{array}{c}\text { Setback } \\
\text { Viscosity } \\
\text { (RVU) }\end{array}$ & $\begin{array}{l}\text { Peak } \\
\text { Time } \\
\text { (min) }\end{array}$ & $\begin{array}{c}\text { Pasting } \\
\text { Temperature } \\
\left({ }^{\circ} \mathrm{C}\right) \\
\end{array}$ \\
\hline $\mathbf{A}$ & $\begin{array}{c}30.34 \\
\pm 0.29^{\mathrm{a}}\end{array}$ & $\begin{array}{c}26.78 \\
\pm 0.19^{\mathrm{a}}\end{array}$ & $\begin{array}{c}3.55 \\
\pm 0.09^{\mathrm{a}}\end{array}$ & $\begin{array}{l}72.56 \\
\pm 0.19^{\mathrm{a}}\end{array}$ & $\begin{array}{l}45.78 \\
\pm 0.39^{\mathrm{a}}\end{array}$ & $\begin{array}{c}6.97 \\
\pm 0.04^{\mathrm{a}}\end{array}$ & $\begin{array}{c}76.18 \\
\pm 0.49^{\text {ab }}\end{array}$ \\
\hline B & $\begin{array}{c}19.91 \\
\pm 0.29^{b}\end{array}$ & $\begin{array}{c}17.25 \\
\pm 1.44^{\mathrm{b}}\end{array}$ & $\begin{array}{c}2.67 \\
\pm 0.14^{\mathrm{b}}\end{array}$ & $\begin{array}{c}42.86 \\
\pm 0.67^{\mathrm{b}}\end{array}$ & $\begin{array}{c}25.61 \\
\pm 0.54^{\mathrm{b}}\end{array}$ & $\begin{array}{c}7.00 \\
\pm 0.00^{\mathrm{a}}\end{array}$ & $\begin{array}{c}74.77 \\
\pm 0.49^{\mathrm{abc}}\end{array}$ \\
\hline C & $\begin{array}{c}15.20 \\
\pm 0.24^{\mathrm{c}}\end{array}$ & $\begin{array}{c}12.86 \\
\pm 0.33^{\mathrm{c}}\end{array}$ & $\begin{array}{c}2.36 \\
\pm 0.09^{\mathrm{c}}\end{array}$ & $\begin{array}{c}30.94 \\
\pm 0.98^{\mathrm{c}}\end{array}$ & $\begin{array}{l}18.00 \\
\pm 0.43^{\mathrm{c}}\end{array}$ & $\begin{array}{c}7.00 \\
\pm 0.00^{\mathrm{a}}\end{array}$ & $\begin{array}{c}73.42 \\
\pm 0.46^{\mathrm{bc}}\end{array}$ \\
\hline D & $\begin{array}{c}8.97 \\
\pm 0.19^{\mathrm{d}}\end{array}$ & $\begin{array}{c}7.92 \\
\pm 0.14^{\mathrm{d}}\end{array}$ & $\begin{array}{c}1.05 \\
\pm 0.04^{\mathrm{d}}\end{array}$ & $\begin{array}{c}15.75 \\
\pm 0.50^{\mathrm{d}}\end{array}$ & $\begin{array}{c}8.17 \\
\pm 0.14^{\mathrm{d}}\end{array}$ & $\begin{array}{c}6.95 \\
\pm 0.00^{\mathrm{ab}}\end{array}$ & $\begin{array}{l}73.42 \\
\pm 0.04^{\mathrm{c}}\end{array}$ \\
\hline $\mathbf{E}$ & $\begin{array}{c}6.89 \\
\pm 0.33^{\mathrm{e}}\end{array}$ & $\begin{array}{c}6.33 \\
\pm 0.43^{\mathrm{e}}\end{array}$ & $\begin{array}{c}0.56 \\
\pm 0.09^{\mathrm{e}}\end{array}$ & $\begin{array}{c}10.70 \\
\pm 0.05^{\mathrm{e}}\end{array}$ & $\begin{array}{c}4.36 \\
\pm 0.49^{\mathrm{e}}\end{array}$ & $\begin{array}{c}6.87 \\
\pm 0.00^{b}\end{array}$ & $\begin{array}{l}76.35 \\
\pm 0.43^{\mathrm{a}}\end{array}$ \\
\hline $\mathbf{F}$ & $\begin{array}{c}5.34 \\
\pm 0.14^{\mathrm{f}}\end{array}$ & $\begin{array}{c}4.84 \\
\pm 0.14^{\mathrm{f}}\end{array}$ & $\begin{array}{c}0.05 \\
\pm 0.00^{\mathrm{e}}\end{array}$ & $\begin{array}{c}7.47 \\
\pm 0.05^{\mathrm{f}}\end{array}$ & $\begin{array}{c}2.64 \\
\pm 0.10^{\mathrm{f}}\end{array}$ & $\begin{array}{c}6.91 \\
\pm 0.07^{\mathrm{ab}}\end{array}$ & $\begin{array}{c}74.97 \\
\pm 1.27^{\mathrm{abc}}\end{array}$ \\
\hline
\end{tabular}

Key a-f: Means with the same superscripts within each row are not significantly different $(\mathrm{p} \geq 0.05)$ 


\section{Physical properties of biscuit samples}

The physical properties of the biscuit samples prepared from maize and okara flour blends are shown in Table 4.

Physical properties of biscuits with different level of okara

Table 4

\begin{tabular}{|c|c|c|c|c|c|c|c|}
\hline \multirow[t]{2}{*}{ Sample } & \multirow{2}{*}{$\begin{array}{c}\text { Weight } \\
\text { (g) }\end{array}$} & \multirow{2}{*}{$\begin{array}{l}\text { Diameter } \\
(\mathbf{m m})\end{array}$} & \multirow{2}{*}{$\begin{array}{c}\text { Thickness } \\
\text { (mm) }\end{array}$} & \multirow{2}{*}{$\begin{array}{c}\text { Spread } \\
\text { ratio }\end{array}$} & \multicolumn{3}{|c|}{ Colour attributes } \\
\hline & & & & & $\mathbf{L}^{*}$ & $\mathbf{b}^{*}$ & $\mathbf{a}^{*}$ \\
\hline $\mathbf{A}$ & $\begin{array}{c}18.18 \\
\pm 0.50^{\mathrm{a}}\end{array}$ & $\begin{array}{c}11.39 \\
\pm 0.16^{\mathrm{b}}\end{array}$ & $\begin{array}{c}1.63 \\
\pm 0.07^{\mathrm{a}}\end{array}$ & $\begin{array}{c}6.99 \\
\pm 0.40^{\mathrm{ab}}\end{array}$ & $\begin{array}{c}85.69 \\
\pm 0.06^{\mathrm{a}}\end{array}$ & $\begin{array}{c}0.88 \\
\pm 0.09^{\mathrm{c}}\end{array}$ & $\begin{array}{c}24.56 \\
\pm 0.06^{\mathrm{d}}\end{array}$ \\
\hline B & $\begin{array}{c}17.72 \\
\pm 0.80^{\mathrm{ab}}\end{array}$ & $\begin{array}{c}13.10 \\
\pm 1.27^{\mathrm{a}}\end{array}$ & $\begin{array}{c}1.64 \\
\pm 0.05^{\mathrm{a}}\end{array}$ & $\begin{array}{c}7.99 \\
\pm 0.68^{\mathrm{a}}\end{array}$ & $\begin{array}{c}84.26 \\
\pm 0.11^{\mathrm{b}}\end{array}$ & $\begin{array}{c}0.93 \\
\pm 0.12^{\mathrm{bc}}\end{array}$ & $\begin{array}{c}25.96 \\
\pm 0.18^{\mathrm{cd}}\end{array}$ \\
\hline C & $\begin{array}{c}17.73 \\
\pm 0.96^{\mathrm{ab}}\end{array}$ & $\begin{array}{c}12.90 \\
\pm 0.97^{\mathrm{ab}}\end{array}$ & $\begin{array}{c}1.79 \\
\pm 0.08^{\mathrm{a}}\end{array}$ & $\begin{array}{c}7.21 \\
\pm 0.30^{\mathrm{ab}}\end{array}$ & $\begin{array}{c}83.60 \\
\pm 0.19^{c}\end{array}$ & $\begin{array}{c}1.12 \\
\pm 0.03^{\mathrm{bcd}}\end{array}$ & $\begin{array}{c}26.67 \\
\pm 0.11^{\mathrm{cd}}\end{array}$ \\
\hline D & $\begin{array}{c}17.46 \\
\pm 0.30^{\mathrm{ab}}\end{array}$ & $\begin{array}{c}13.07 \\
\pm 1.02^{\mathrm{a}}\end{array}$ & $\begin{array}{c}1.63 \\
\pm 0.02^{\mathrm{a}}\end{array}$ & $\begin{array}{c}8.02 \\
\pm 0.59^{\mathrm{a}}\end{array}$ & $\begin{array}{c}83.31 \\
\pm 0.21^{\mathrm{cd}}\end{array}$ & $\begin{array}{c}1.38 \\
\pm 0.13^{\mathrm{a}}\end{array}$ & $\begin{array}{c}27.62 \\
\pm 0.12^{\mathrm{c}}\end{array}$ \\
\hline $\mathbf{E}$ & $\begin{array}{c}17.02 \\
\pm 0.39^{\mathrm{b}}\end{array}$ & $\begin{array}{c}12.81 \\
\pm 0.98^{\mathrm{ab}}\end{array}$ & $\begin{array}{c}1.59 \\
\pm 0.26^{\mathrm{a}}\end{array}$ & $\begin{array}{c}8.06 \\
\pm 0.92^{\mathrm{a}}\end{array}$ & $\begin{array}{l}83.18 \\
\pm 0.07^{\mathrm{d}}\end{array}$ & $\begin{array}{c}1.15 \\
\pm 0.10^{\mathrm{ab}}\end{array}$ & $\begin{array}{c}28.34 \\
\pm 0.35^{\mathrm{b}}\end{array}$ \\
\hline $\mathbf{F}$ & $\begin{array}{c}15.69 \\
\pm 0.11^{\mathrm{c}}\end{array}$ & $\begin{array}{c}13.62 \\
\pm 0.55^{\mathrm{a}}\end{array}$ & $\begin{array}{c}1.71 \\
\pm 0.07^{\mathrm{a}}\end{array}$ & $\begin{array}{c}7.97 \\
\pm 0.04^{\mathrm{a}}\end{array}$ & $\begin{array}{c}81.71 \\
\pm 0.10^{\mathrm{e}}\end{array}$ & $\begin{array}{c}1.35 \\
\pm 0.03^{\mathrm{a}}\end{array}$ & $\begin{array}{c}29.64 \\
\pm 0.38^{\mathrm{a}}\end{array}$ \\
\hline
\end{tabular}

Key a-d: Means with the same superscripts within each row are not significantly different $(\mathrm{p} \geq 0.05)$

The weight of the biscuit samples ranged from 15.69 to $18.18 \mathrm{~g}$. According to the results presented, the addition of okara flour into the formulation decreased the post-bake weight of the products. The reduction in weight is expected due to the fact that okara flour is less dense than maize flour.

The diameter of biscuit samples increased with the inclusion of okara in the formulation. The diameter of the control sample was the lowest $(11.39 \mathrm{~mm})$ while sample $\mathrm{F}$ had the highest diameter $(13.62 \mathrm{~mm})$. It has been reported that the use of non- wheat flour resulted in lower protein gluten and subsequent decrease in viscosity of biscuits dough [29]. Consequently, low dough viscosity results in high flow rate (spread rate) of the dough which contributes to the large diameter of biscuits prepared from composite flours. The thickness of sample E $(1.71 \mathrm{~mm})$ was highest while the lowest value was noted in samples A and D $(1.63 \mathrm{~mm})$. However, there was no significant difference in the thickness of the biscuit samples.

The diameter and thickness reflected in the spread ratio increased with increase in the level of okara in the formulation. The spread ratio of sample A was the lowest (6.99) while the highest was observed in sample E (8.06). The increase in spread ratio reflects poor cohesions of the net work of the protein and carbohydrates which are the major macro elements in the products. The poor cohesion could initiate the outflow of some ingredients such as sugar that could melt at high baking temperature hence increasing the spread ability of the material [30]. 
Evaluation of the surface colour of the biscuit samples across the space CIELAB indicated significant differences regarding the $L^{*}, a^{*}$ and $b^{*}$ values. Comparing the $L^{*}$ values, statistically significant differences were found among the samples. Lower lightness $\left(L^{*}\right)$ values were observed as the level of okara increased in the biscuit samples. This is an indication that samples containing different level of okara flour present darker color compared with the control. The increase in color values could be attributed to the interaction between protein and sugar during baking which resulted in higher degree of Maillard reaction.

Similarly, the variation in composite formulation as marked by increase in the level of okara increased $a^{*}$ and $b^{*}$ values. Soybean contains high amount of carotenoid and there is retention of the pigment in okara flour. Similarly, the maize variety used in this study has yellow (carotenoid) colour. This explains reduction in $\mathrm{L}^{*}$ value and predominance of redness $\left(a^{*}\right)$ and yellowness $\left(b^{*}\right)$ values observed in okara supplemented biscuit samples.

\section{Chemical composition of biscuit samples}

The proximate composition of the biscuit samples was significantly different at $5 \%$ level of significance as indicated in Table 5.

Proximate composition of biscuits with different level of okara

Table 5

\begin{tabular}{|c|c|c|c|c|c|c|c|}
\hline Sample & $\begin{array}{l}\text { Moisture } \\
\text { (\%) }\end{array}$ & $\begin{array}{l}\text { Ash } \\
(\%)\end{array}$ & $\begin{array}{c}\text { Protein } \\
(\%)\end{array}$ & $\begin{array}{l}\text { Fat } \\
(\%)\end{array}$ & $\begin{array}{c}\text { Fibre } \\
(\%)\end{array}$ & $\begin{array}{c}\text { Carbohydrate } \\
(\%)\end{array}$ & $\begin{array}{l}\text { Energy } \\
\mathrm{kCal} / \mathbf{1 0 0 g}\end{array}$ \\
\hline $\mathbf{A}$ & $\begin{array}{c}4.53 \\
\pm 0.81^{\mathrm{c}}\end{array}$ & $\begin{array}{c}1.00 \\
\pm 0.26^{\mathrm{c}}\end{array}$ & $\begin{array}{c}7.79 \\
\pm 0.01^{\mathrm{f}}\end{array}$ & $\begin{array}{c}17.77 \\
\pm 0.01^{\mathrm{f}}\end{array}$ & $\begin{array}{c}1.91 \\
\pm 0.64^{\mathrm{f}}\end{array}$ & $\begin{array}{c}67.00 \\
\pm 0.19^{\mathrm{a}}\end{array}$ & $\begin{array}{l}406.93 \\
\pm 1.03^{\mathrm{ab}}\end{array}$ \\
\hline B & $\begin{array}{c}4.57 \\
\pm 0.19^{\mathrm{c}}\end{array}$ & $\begin{array}{c}0.98 \\
\pm 0.09^{\mathrm{c}}\end{array}$ & $\begin{array}{c}11.52 \\
\pm 0.03^{\mathrm{e}}\end{array}$ & $\begin{array}{c}19.55 \\
\pm 0.05^{\mathrm{e}}\end{array}$ & $\begin{array}{c}2.36 \\
\pm 0.25^{\mathrm{e}}\end{array}$ & $\begin{array}{c}61.02 \\
\pm 0.59^{b}\end{array}$ & $\begin{array}{l}409.58 \\
\pm 1.14^{\mathrm{a}}\end{array}$ \\
\hline C & $\begin{array}{c}4.72 \\
\pm 0.23^{\mathrm{bc}}\end{array}$ & $\begin{array}{c}1.26 \\
\pm 0.25^{\mathrm{bc}}\end{array}$ & $\begin{array}{c}12.32 \\
\pm 0.02^{\mathrm{d}}\end{array}$ & $\begin{array}{c}19.95 \\
\pm 0.01^{\mathrm{d}}\end{array}$ & $\begin{array}{c}3.08 \\
\pm 0.09^{d}\end{array}$ & $\begin{array}{c}58.67 \\
\pm 0.44^{\mathrm{c}}\end{array}$ & $\begin{array}{l}406.49 \\
\pm 0.83^{\mathrm{ab}}\end{array}$ \\
\hline D & $\begin{array}{c}4.80 \\
\pm 0.15^{\mathrm{bc}}\end{array}$ & $\begin{array}{c}1.37 \\
\pm 0.17^{\mathrm{bc}}\end{array}$ & $\begin{array}{c}14.37 \\
\pm 0.01^{\mathrm{c}}\end{array}$ & $\begin{array}{l}20.42 \\
\pm 0.02^{\mathrm{c}}\end{array}$ & $\begin{array}{c}3.86 \\
\pm 0.16^{\mathrm{c}}\end{array}$ & $\begin{array}{c}55.18 \\
\pm 0.20^{\mathrm{d}}\end{array}$ & $\begin{array}{l}402.97 \\
\pm 1.00^{\mathrm{b}}\end{array}$ \\
\hline $\mathbf{E}$ & $\begin{array}{c}5.04 \\
\pm 0.06^{\mathrm{b}}\end{array}$ & $\begin{array}{c}1.53 \\
\pm 0.13^{\mathrm{a}}\end{array}$ & $\begin{array}{c}17.86 \\
\pm 0.01^{b}\end{array}$ & $\begin{array}{c}20.64 \\
\pm 0.01^{b}\end{array}$ & $\begin{array}{c}4.46 \\
\pm 0.16^{\mathrm{b}}\end{array}$ & $\begin{array}{l}50.47 \\
\pm 0.61^{\mathrm{e}}\end{array}$ & $\begin{array}{l}396.51 \\
\pm 0.97^{\mathrm{c}}\end{array}$ \\
\hline $\mathbf{F}$ & $\begin{array}{c}5.68 \\
\pm 0.25^{\mathrm{a}}\end{array}$ & $\begin{array}{c}1.63 \\
\pm 0.08^{\mathrm{a}}\end{array}$ & $\begin{array}{c}18.62 \\
\pm 0.02^{\mathrm{a}}\end{array}$ & $\begin{array}{l}21.15 \\
\pm 0.01^{\mathrm{a}}\end{array}$ & $\begin{array}{c}5.28 \\
\pm 0.56^{\mathrm{a}}\end{array}$ & $\begin{array}{l}47.64 \\
\pm 0.69^{\mathrm{f}}\end{array}$ & $\begin{array}{c}392.53 \\
\pm 1.11^{\mathrm{cd}}\end{array}$ \\
\hline
\end{tabular}

Key a-f: Means with the same superscripts within each row are not significantly different ( $\geq 0.05)$

Moisture content of the biscuit samples was within the range of 4.53 to $5.68 \%$. The highest moisture content was noted in Sample F while there was no significant difference between other samples. The supplementation of maize flour with okara flour at 10 to $50 \%$ level significantly $(p \leq 0.05)$ increased the moisture content of biscuit samples. This is attributed to the fact that the protein and fibre in soy flour are hygroscopic in nature hence absorb and retain higher amount of moisture during the baking process. 
Significant difference $(\mathrm{p} \leq 0.05)$ was observed in the fat content of the biscuit samples. The fat content ranged between 17.8-20.6\%. The highest value of fat content was determined in biscuits prepared from 50\% maize flour and 50\% okara, whereas the lowest value of fat content recorded in biscuits prepared from $100 \%$ maize flour. The increase in fat content as the level of okara increases could be as a result of relatively higher amount of fat in the okara flour. Similar observation was reported by Rita and Adiza [31].

Data presented in Table 5 clearly show that supplementation of maize flour with different level of okara flour increased the protein content of biscuit samples. Protein content of biscuit samples ranged from 7.8 to $18.6 \%$. The maximum protein content was found in biscuits prepared from the flour blends of 50\% maize flour and 50\% okara flour while lowest protein content was found in biscuits made from $100 \%$ okara flour. The protein content was observed to increase with progressive increase in proportion of okara flour. The increase might be due to the high protein content of soybean. The results of the present study are supported by the earlier report of Tasnima [32] that established an increase in protein content of biscuits prepared from soybean and wheat flour.

The ash content of the biscuit samples varied between 0.93 to $1.63 \%$. The highest ash content was observed in samples $\mathrm{E}$ and $\mathrm{F}$, while there was no significant difference between other samples. The result of this study indicated that the ash content was significantly higher in the biscuit samples containing okara flour compared with the control. This is an indication that okara flour is a good source of mineral elements. Earlier report had indicated that legumes are good sources of ash [32].

The fibre content of biscuit samples varied between 1.91-5.28\%. Biscuits prepared from blends of 50\% maize flour and 50\% okara flour showed the highest value. In contrast, biscuit sample prepared from $100 \%$ maize flour had the lowest fibre content. The fibre content was observed to increase with the increase in proportion of okara flour in the formulation. Soybeans contain appreciable quantity of fibre and much more is expected in its residue after milk extraction. The increased fibre content of the biscuit sample is advantageous as it will prevent the indigestion often associated with products from refined grain flours. Asides, it has been reported that okara supplementation in human diet yielded a decrease in body weight, beneficial properties on lipid metabolism, protected the gut environment in terms of antioxidant status, as well as prebiotic effects [33].

The carbohydrate content of biscuit samples ranged between 47.6 to $67.0 \%$. The highest value was observed in biscuit sample prepared from $100 \%$ maize flour whereas biscuit prepared from 50\% maize and 50\% okara had the least. It could be inferred that okara flour is not a good source of carbohydrate when compared with maize. Rita and Adiza [31] also authenticated that addition of soybean flour reduced the carbohydrate content in fortified biscuits.

The gross energy of biscuits samples varied from 392.53 to $409.58 \mathrm{kCal} / 100 \mathrm{~g}$. With the increase of okara, a significant decrease in value of kilocalories per $100 \mathrm{~g}$ was obtained. The slight decrease in the energy density of biscuit samples containing different level of okara was mainly due to the lower carbohydrate content than the control sample.

The oxalate content of the biscuit samples ranged from $0.37-0.73 \mathrm{mg} / 100 \mathrm{~g}$ as indicated in Table 6 . The oxalate concentration was significantly affected by the proportion of okara in the formulation used for biscuit preparation. The highest oxalate content was determined in the biscuit samples containing $50 \%$ of maize and $50 \%$ of okara while the control biscuit contains no oxalate. In essence, the concentration of oxalate in the biscuit samples increased with the level of okara in the formulation. This is a clear indication that soybean contains oxalate. The presence of oxalate in the biscuit samples could have effect on nutrients bioavailability and absorption. 
Anti-nutrient composition of biscuits with different level of okara

\begin{tabular}{|c|c|c|c|}
\hline Sample & Phytate (mg/g) & Oxalate (mg/g) & Tannin (mg/g) \\
\hline A & ND & ND & $0.53 \pm 0.33^{\mathrm{a}}$ \\
B & $0.03 \pm 0.02^{\mathrm{d}}$ & $0.37 \pm 0.334^{\mathrm{b}}$ & $1.16 \pm 0.33^{\mathrm{b}}$ \\
C & $0.04 \pm 0.03^{\mathrm{cd}}$ & $0.49 \pm 0.400^{\mathrm{b}}$ & $1.34 \pm 0.33^{\mathrm{c}}$ \\
D & $0.04 \pm 0.02^{\mathrm{bc}}$ & $0.67 \pm 0.001^{\mathrm{a}}$ & $1.36 \pm 0.33^{\mathrm{c}}$ \\
E & $0.04 \pm 0.02^{\mathrm{b}}$ & $0.70 \pm 0.113^{\mathrm{a}}$ & $1.41 \pm 0.33^{\mathrm{cd}}$ \\
F & $0.06 \pm 0.04^{\mathrm{a}}$ & $0.73 \pm 0.020^{\mathrm{a}}$ & $1.47 \pm 0.33^{\mathrm{d}}$ \\
\hline
\end{tabular}

Key a-d: Means with the same superscripts within each row are not significantly different $(\mathrm{p} \geq 0.05)$.

ND: not detected

Hence, oxalate is one of the factors to be considered during optimizing the proportion of okara supplemented with maize for biscuit production though the lethal dose of oxalate has been reported to be between 2 and $5 \mathrm{~g} / \mathrm{kg}$ for man [34].

Phytate content of the biscuit samples ranged from 0.03 to $0.06 \mathrm{mg} / 100 \mathrm{~g}$. Biscuits prepared from $100 \%$ maize flour were devoid of phytate. The highest concentration of phytate was recorded in the biscuit samples prepared from the proportion of $50 \%$ maize flour and $50 \%$ okara. In present study, phytate content increased with increase in supplementation with soy okara in the biscuit samples. This might be due to the high amount of phytate content found in okara [35]. However, the quantity of phytate in the biscuit samples is below the recommended limit in the diet $(250-500 \mathrm{mg} / 100 \mathrm{~g})$ as reported by Ekop et al [36].

Tannin content of biscuit samples ranged from 0.53 to $1.47 \mathrm{mg} / 100 \mathrm{~g}$ and was significantly affected by the level of okara in the formulation. The highest tannin content was reported in the biscuit samples prepared from $50 \%$ of maize and $50 \%$ of okara while the lowest value was noted in the control sample. This indicates that the concentration of tannin in the biscuits increased as the level of okara in the formulation increased. Furthermore, the tannin concentrations in all the biscuit samples were below the level acceptable in a food which is $2 \mathrm{~g} / 100 \mathrm{~g}$ [37]. Avoidance of products with levels of tannins exceeding this threshold should be a criterion in food selection.

\section{Sensorial characteristics of biscuit samples}

The sensorial ratings of the biscuit samples were presented in Table 7 .

The highest colour score was presented in sample C followed by sample $\mathrm{E}$ and lowest for the control sample. However, there was no significant difference among the samples. This could be attributed to similarity in the colour of maize flour and okara flour. Both grains used in this study have yellow colour which made it difficult for the panellist to identify the difference as the level of okara in the blend increases. 
Sensorial characteristics of biscuits with different level of okara

\begin{tabular}{|c|c|c|c|c|c|c|c|}
\hline Sample & Colour & Taste & Sweetness & Hardness & Crunchiness & Aroma & $\begin{array}{c}\text { Overall } \\
\text { acceptability }\end{array}$ \\
\hline $\mathbf{A}$ & $\begin{array}{c}1.75 \\
\pm 0.55^{\mathrm{a}}\end{array}$ & $\begin{array}{c}2.15 \\
\pm 0.75^{\mathrm{a}}\end{array}$ & $\begin{array}{c}2.15 \\
\pm 0.81^{\mathrm{ab}}\end{array}$ & $\begin{array}{c}2.20 \\
\pm 1.11^{\mathrm{a}}\end{array}$ & $\begin{array}{c}1.80 \\
\pm 0.77^{\mathrm{b}}\end{array}$ & $\begin{array}{c}1.80 \\
\pm 0.77^{\mathrm{b}}\end{array}$ & $\begin{array}{c}1.95 \\
\pm 0.67^{\mathrm{b}}\end{array}$ \\
\hline B & $\begin{array}{c}1.80 \\
\pm 0.77^{\mathrm{a}}\end{array}$ & $\begin{array}{c}2.05 \\
\pm 0.95^{\mathrm{a}}\end{array}$ & $\begin{array}{c}2.00 \\
\pm 0.73^{\mathrm{b}}\end{array}$ & $\begin{array}{c}2.45 \\
\pm 1.19^{\mathrm{a}}\end{array}$ & $\begin{array}{c}2.00 \\
\pm 0.80^{\mathrm{ab}}\end{array}$ & $\begin{array}{c}2.30 \\
\pm 0.92^{\mathrm{ab}}\end{array}$ & $\begin{array}{c}2.05 \\
\pm 0.89^{\mathrm{ab}}\end{array}$ \\
\hline $\mathbf{C}$ & $\begin{array}{c}2.15 \\
\pm 1.04^{\mathrm{a}}\end{array}$ & $\begin{array}{c}2.45 \\
\pm 1.00^{\mathrm{a}}\end{array}$ & $\begin{array}{c}2.65 \\
\pm 0.88^{\mathrm{ab}}\end{array}$ & $\begin{array}{c}2.40 \\
\pm 0.94^{\mathrm{a}}\end{array}$ & $\begin{array}{c}2.65 \\
\pm 0.88^{\mathrm{a}}\end{array}$ & $\begin{aligned} & 2.70 \\
\pm & 1.03^{\mathrm{ab}}\end{aligned}$ & 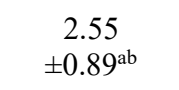 \\
\hline D & $\begin{array}{c}1.90 \\
\pm 0.85^{\mathrm{a}}\end{array}$ & $\begin{array}{c}2.30 \\
\pm 1.03^{\mathrm{a}}\end{array}$ & $\begin{array}{c}2.50 \\
\pm 1.05^{\mathrm{ab}}\end{array}$ & $\begin{array}{c}2.45 \\
\pm 0.95^{\mathrm{a}}\end{array}$ & $\begin{array}{c}2.20 \\
\pm 0.89^{\mathrm{ab}}\end{array}$ & $\begin{aligned} & 2.25 \\
\pm & 0.97^{\mathrm{ab}}\end{aligned}$ & $\begin{array}{c}2.25 \\
\pm 0.91^{\mathrm{ab}}\end{array}$ \\
\hline $\mathbf{E}$ & $\begin{array}{c}2.05 \\
\pm 0.76^{\mathrm{a}}\end{array}$ & $\begin{array}{c}2.70 \\
\pm 1.03^{\mathrm{a}}\end{array}$ & $\begin{array}{c}2.95 \\
\pm 1.15^{\mathrm{a}}\end{array}$ & $\begin{array}{c}3.10 \\
\pm 1.02^{\mathrm{a}}\end{array}$ & $\begin{array}{c}2.80 \\
\pm 1.06^{\mathrm{a}}\end{array}$ & $\begin{array}{c}3.05 \\
\pm 1.36^{\mathrm{a}}\end{array}$ & $\begin{array}{c}2.80 \\
\pm 1.15^{\mathrm{a}}\end{array}$ \\
\hline $\mathbf{F}$ & $\begin{array}{c}2.00 \\
\pm 0.80^{\mathrm{a}}\end{array}$ & $\begin{array}{c}2.60 \\
\pm 0.95^{\mathrm{a}}\end{array}$ & $\begin{array}{c}2.40 \\
\pm 0.94^{\mathrm{ab}}\end{array}$ & $\begin{array}{c}2.25 \\
\pm 0.91^{\mathrm{a}}\end{array}$ & $\begin{array}{c}2.70 \\
\pm 0.87^{\mathrm{a}}\end{array}$ & $\begin{array}{c}2.75 \\
\pm 0.85^{\mathrm{a}}\end{array}$ & $\begin{array}{c}2.40 \\
\pm 0.94^{\mathrm{ab}}\end{array}$ \\
\hline
\end{tabular}

Key a-e: Means with the same superscripts within each row are not significantly different $(\mathrm{p} \geq 0.05)$.

The scores for aroma ranged from 1.80 to 3.05 . The highest value (3.05) was noted in sample E while the control sample had the least value (1.80). There was significant difference $(\mathrm{p} \leq 0.05)$ among the samples. Likewise, in term of taste, sample $\mathrm{E}$ was most preferred with a score of 2.70 while sample B was least preferred with a score of 2.05 although there was no significant difference among the samples.

There were significant differences $(\mathrm{p} \leq 0.05)$ between the samples in terms of crunchiness. An increase in the supplementation level of maize flour with okara resulted in higher scores which may be attributed to the low fat absorption capacity of okara flour as indicated in Table 2. The hardness measured by force applied to break the biscuits was significantly affected by increase in okara flour supplementation in the formulation. Biscuit sample containing different levels of okara are expected to be harder due to higher percentages of fibre and protein in okara which resulted in compact dough structure compared with the control. Moreso, the hardness of the samples containing okara can be attributed to higher water absorption capacity of the flour blends as indicated in Table 2 . Earlier study had reported a positive relation between dietary fibre, hardness and chewiness [38].

The results indicated that all the biscuit samples presented good acceptability in terms of sweetness. Considering overall acceptability, sample E was most preferred among the biscuits produced from the flour blends. The result showed that supplementation of maize flour with different level of okara had minimal impact on the sensorial attributes of the biscuits. 


\section{Conclusions}

1. In this study, it has been established that maize flour could be supplemented with okara flour to obtain biscuits with acceptable physical, nutritional and sensorial characteristics.

2. In terms of general acceptability, biscuit formulation of $60 \%$ maize flour and $40 \%$ okara flour was most preferred among the biscuits produced from the flour blends.

3. The study reveals that the application of okara could be widen with optimal conditions to generate not only nutritional benefits but also environmental significance.

\section{References}

1. Onabanjo O. O., Ighere D. A. (2014), Nutritional, functional and sensory properties of biscuit produced from wheat-sweet potato composite. Journal of Food Technology Research, 1, pp.111-121.

2. Abayomi H.T., Oresanya T.O., Opeifa A.O., Rasheed T. R. (2013), Quality evaluation of cookies produced from blends of sweet potato and fermented soybean flour. International Journal of Biological, Food, Veterinary and Agricultural Engineering, 7, pp.350-355.

3. FSAIFR (2002), Food Standards Agency and Institute of Food Research. McCance and Widdowson's The Composition of Foods, Sixth Summary Edition. Royal Society of Chemistry, Cambridge.

4. Farnham D.E., Benson G.O., Pearce R.B. (2003), Corn perspective and culture, In: PJ White, LA Johnson, eds. Corn: chemistry and technology, Edition 2nd. American Association of Cerial Chemicals, Inc. St. Paul, Minesota, USA, pp. 1-33.

5. Oladejo J.A., Adetunji M.O.(2012): Economic analysis of maize (zea mays) production in Oyo state of Nigeria. Agricultural Science Research Journals, 2(2), pp. 77-83

6. Arendt E.K., Zannini E. (2013), Cereal Grains for the Food and Beverage Industries. Woodhead Publishing Limited, pp, 67-113.

7. CRA (2006), Corn oil (5th ed.), Corn Refiners Association. Washington, DC.

8. Jang S.E., Lim J.W., Kim H. (2009), Mechanism of $\beta$-Carotene-Induced Apoptosis of Gastric Cancer Cells: Involvement of Ataxia-Telangiectasia-Mutated. Annals of the New York Academy of Sciences, 1171(1), pp.156-62.

9. Nwokolo E. (1996), Soybean (Glycine $\max$ (L.) Merr.), In book: Food and feed from legumes and oilseeds, pp.90-102.

10. Qstermann-Porcel M.V., Quiroga-Panelo N., Rinaldoni A.N., Campderros M.E. (2017), Incorporation of okara into gluten-free cookies with high quality and nutritional value. Journal of Food Quality, pp. 8.

11. Swalla M.S., Fan H., Wang S., Yu H., Piao C. (2021), Prebiotic impacts of soybean residue (okara) on eubiosis/dysbiosis condition of the gut and the possible effects on liver and kidney functions. Molecules, 26, pp.326.

12. Onabanjo O.O., Akinyemi C. O., Agbon C.A. (2009), Characteristics of complementary foods produced from sorghum, sesame, carrot and crayfish. Journal of Natural Sciences and Engineering, 8, pp. 71-83.

13. Appiah F., Asibuo J.Y., Kumah P. (2011), Physicochemical and functional properties of bean flours of three cowpea (Vigna unguiculata L.) varieties in Ghana. African Journal of Food Science, 5, pp. 100-104.

14. Sofi B.A., Wani I.A., Masoodi F.A., Saba I., Muzaffar S. (2013), Effect of gamma irradiation on physicochemical properties of broad bean (Vicia faba L.) starch. LWT-Food Science and Technology, 54, pp. 63-72. 
15. Wani A.A., Wani I.A., Hussain P.R., Gani A., Wani T.A., Masoodi, F.A. (2015), Physicochemical properties of native and ã-irradiated wild arrowhead (Sagittaria sagittifolia L.) tuber starch. International Journal of Biological Macromolecule., 77, pp. $360-368$.

16. AACC (2000), Approved methods of the American Association of Cereal Chemists, 10th ed., Minnesota, USA, pp. 150-192.

17. AOAC (2012), The official methods of analysis. In 19th Ed. Association of Official Analytical Chemist, Gaithersburg, Maryland, USA.

18. Ekanayake S., Jans E.R., Nair, B.M. (1999), Proximate composition, mineral and amino acid content of mature Canavalia gladiata seeds. Food Chemistry,66, pp. 115-119.

19. Oladele K.A., Osundahunsi F.O., Adebowale A.Y.(2009), Influence of processing techniques on the nutrients and nutrients of tiger nuts (Cyperus esculentus L.), World Journal of Dairy and Food Sciences, 4, pp. 88-93.

20. Mugaboa E., Emmanuel O.A., George A., Bernard R. (2017), Effect of pre-treatments and processing conditions on anti-nutritional factors in climbing bean flours. International Journal of Food Studies, 6, pp. 34-43.

21. Adebowale K.O., Lawal O.S. (2004), Comparative study of the functional properties of bambara groundnut (Voandzeia subterranean), jack bean (Cavanalia ensiformis) and mucuna bean (Mucuna pruriens), Food Research International, 37, pp. 355-365.

22. Wang L., Seib P.A. (1996), Australian salt-noodle flours and their starches compared with U.S. wheat flours and their starches. Cereal Chemistry, 73, pp.167-175.

23. Sasaki T., Matsuki J. (1998), Effects of wheat starch structure on swelling power. Cereal Chemistry, 75, pp. 525-529.

24. Sanni L.O., Ikuomola D.P., Sanni S.A. (2001), Effect of length of fermentation and varieties on the qualities of sweet potato garri: Proceedings of the $8^{\text {th }}$ Triennial Symposium of the International Society for Tropical Root Crops. Africa Branch (ISTRC-AB), November, 12 16, 2001, IITA, Ibadan, Nigeria, pp. 208-211.

25. Maziya-Dixon B., Dixon A.G.O., Adebowale A.A (2004), Targeting different and users of cassava; genotype variations for cyanogenic potentials and pasting properties: A paper presented at ISTRC AB symposium, October 31-November 5, 2004, Whitesand Hotel, Mombasu, Kenya.

26. Julianti E., Rusmarilin H.,Yusraini E. (2015), Functional and rheological properties of composite flour from sweet potato, maize, soybean and xanthan gum. Journal of the Saudi Society of Agricultural Sciences, 16, pp.171-177.

27. Sasaki T., Yasui T., Matsuki, J. (2000), Effect of amylose content on gelatinization, retrogradation and pasting properties of starches from waxy and non-waxy wheat and their F1 seeds. Journal of Cereal Chemistry, 77 (1), pp.58-63.

28. Singh N., Singh J., Kaur L., Sodhi N.S., Gill, B.S. (2003), Morphological, thermal and rheological properties of starches from different botanical sources. Food Chemistry, 81, pp. 219-231.

29. Miller R.A., Hoseney R.C., Morris C.F. (1997), Effect of formula water content on the spread of sugar-snap cookies. Cereal Chemistry, 74, pp. 669-671.

30. Ayo J.A., Nkama I. (2003), Effect of acha (Digitaria exilis Staph) grain flours on the physical and sensory quality of biscuit. Nutrition and Food Science, 33,pp. 125-130.

31. Rita E.S., Adiza S.S.D. (2010), Nutritional and aensory analysis of soy bean and wheat flour composite cahe. Pakistan Journal of Nutrition, 9(8), pp. 794-794.

32. Tasnima F.S.M. (2015), Effect of incorporation of soy flour to wheat flour on nutritional and sensory quality of biscuits fortified with mushroom. Food Science and Nutrition, 3(5), pp. 363-369. 
33. Villanueva M., Yokoyama W., Hong Y., Barttley G., Rupérez P. (2011), Effect of high-fat diets supplemented with okara soybean by-product on lipid profiles of plasma, liver and faeces in Syrian hamsters. Food Chemistry, 124, pp. 72-79.

34. Eneobong H.N. (2001), Eating right (A nutrition guide), Nigeria: Zoometer Print Communications Ltd.

35. Li B., Qiao M., Lu F. (2012), Composition, nutrition and utilization of okara (soybean residue), Food Reviews International, 28(3), pp. 231-252.

36. Ekop A.S., Obot I.B., Ikpatt E.N. (2008), Anti-nutritional factors and potassium bromate content in bread and flour samples in Uyo metropolis, Nigeria. European Journal of Chemistry, 5, pp. 736-741.

37. Okaraonye C.C, Ikewuchi J.C. (2009), Nutritional and antinutritional components of Pennisetum purpureum (Schumach), Pakistan Journal of Nutrition, 8(1), pp.32-34.

38. Gomez M., Ronda F., Caballero P.A., Blanco C.A., Rosell C.M. (2007), Functionality of different hydrocolloids on the quality and shelf life of yellow layer cake. Food Hydrocolloids, 21, pp.167-173. 